\title{
ESI-MS fragmentation pathways of some 1,2,4-triazole- 3-thiones, the intermediate compounds in the synthesis of active pharmaceutical ingredients
}

Aim. To determine the fragmentation pathways of eight 1,2,4-triazole-3-thiones, which are intermediate products in the synthesis of active pharmaceutical ingredients of potential and registered pharmaceutical formulations.

Results and discussion. HPLC-MS analysis of eight 1,2,4-triazole-3-thiones, which are intermediate products in the synthesis of salts of 1,2,4-triazolylthioacetate acids, has been carried out; the mass spectra of the compounds to be analyzed have been registered in ESI-mode with different fragmentor voltage $(0,100,200 \mathrm{~V})$. The fragmentation pathways and patterns of ion decay for compounds to be analyzed have been proposed.

Experimental part. Agilent 1260 Infinity HPLC System with Agilent 6120 mass spectrometer were used. HPLC-MS conditions: column - $\varnothing 4,6 \times 30 \mathrm{~mm}$, reversible phase Zorbax SB C18, $1.8 \mu \mathrm{m}, 40^{\circ} \mathrm{C}$; mobile phase $0.1 \% \mathrm{HCOOH}$ in $\mathrm{H}_{2} \mathrm{O}$ and $0.1 \% \mathrm{HCOOH}$ in $\mathrm{CH}_{3} \mathrm{CN}$ in isocratic mode $(50: 50$, v/v); the flow rate $-0.4 \mathrm{~mL} / \mathrm{min}$; ion source - API-ES; positive polarity; drying gas - nitrogen (rate - $10 \mathrm{~L} / \mathrm{min}$ ); the capillary voltage $-4000 \mathrm{~V}$; scanning in the range of $\mathrm{m} / \mathrm{z} 100-1000$.

Conclusions. For the first time it has been interpreted the mass spectra of 1,2,4-triazole-3-thiones series, the intermediate compounds in the synthesis of active pharmaceutical ingredients of pharmaceutical formulations. The fragmentation pathways and patterns of eight 1,2,4-triazole-3-thiones have been shown.

Key words: mass spectrometry; high performance liquid chromatography; 1,2,4-triazole-3-thiones

Б. О. Варинський, А. Г. Каплаушенко

Запорізький державний медичний університет, Україна

Шляхи ECI-MC фрагментації деяких 1,2,4-триазол-3-тіонів, проміжних продуктів при синтезі активних фармацевтичних інгредієнтів

Мета. Визначити шляхи фрагментації восьми 1,2,4-триазол-3-тіонів, які є проміжними продуктами в синтезі активних фрармацевтичних інгредієнтів потенційних та зареєстрованих фрармацевтичних препаратів.

Результати та їх обговорення. Проведено BEPX-MC аналіз восьми 1,2,4-триазол-3-тіонів, які $\epsilon$ проміжними продуктами при синтезі солей 1,2,4-триазолілтіоацетатних кислот; мас-спектри досліджуваних сполук зареєстровано в ECI-режимі з різною напругою фррагментатора (0, 100, 200 В). Запропоновано шляхи фррагментації та закономірності розпаду іонів для аналізованих сполук.

Експериментальна частина. Для досліджень використано систему HPLC Agilent 1260 Infinity 3 масспектрометром Agilent 6120. BEPX-MC умови: колонка - $\varnothing 4,6$ × 30 мм, обернена фаза Zorbax SB C18, 1,8 $\mu \mathrm{m}$, $40^{\circ} \mathrm{C}$; рухома фраза $-0,1 \% \mathrm{HCOOH}$ в $\mathrm{H}_{2} \mathrm{O}$ та $0,1 \% \mathrm{HCOOH}$ в $\mathrm{CH}_{3} \mathrm{CN}$ в ізократичному режимі $(50: 50$, v/v); швидкість потоку - 0,4 мл/хв; джерело іонів - API-ES; позитивна полярність; газ-осушувач - азот (швидкість - 10 л/хв); напруга капіляра - 4000 V; сканування в діапазоні m/z 100 - 1000.

Висновки. Вперше інтерпретовано мас-спектри серії 1,2,4-триазол-3-тіонів, проміжних сполук при синтезі активних фрармацевтичних інгредієнтів фрармацевтичних препаратів. Показано шляхи фррагментації та розпаду восьми 1,2,4-триазол-3-тіонів.

Ключові слова: мас-спектрометрія; високоефективна рідинна хроматографія; 1,2,4-триазол-3-тіони

Б. А. Варинский, А. Г. Каплаушенко

Запорожский государственный медицинский университет, Украина

Пути ЭСИ-МС фрагментации некоторых 1,2,4-триазол-3-тионов, промежуточных

продуктов при синтезе активных фармацевтических ингредиентов

Цель. Определить пути фрагментации восьми 1,2,4-триазол-3-тионов, являющихся промежуточными продуктами в синтезе активных фармацевтических ингредиентов потенциальных и зарегистрированных фармацевтических препаратов.

Результаты и их обсуждение. Проведен ВЭЖХ-МС анализ восьми 1,2,4-триазол-3-тионов, являющихся промежуточными продуктами при синтезе солей 1,2,4-триазолилтиоацетатних кислот; масс-спектры исследуемых соединений зарегистрированы в ЭСИ-режиме с различным напряжением фрагментатора $(0,100,200$ В). Предложены пути фрагментации и закономерности распада ионов для исследуемых соединений.

Экспериментальная часть. Для исследований использована система HPLC Agilent 1260 Infinity с масcспектрометром Agilent 6120. ВЭЖX-МС условия: колонка - $\varnothing 4,6$ × 30 мм, обращенная фраза Zorbax SB C18, $1,8 \mu \mathrm{m}, 40^{\circ} \mathrm{C}$; подвижная фаза $-0,1 \% \mathrm{HCOOH}$ в $\mathrm{H}_{2} \mathrm{O}$ и $0,1 \% \mathrm{HCOOH}$ в $\mathrm{CH}_{3} \mathrm{CN}$ в изократическом режиме (50:50, v/v); скорость потока - 0,4 мл/мин; источник ионов - API-ES; позитивная полярность; газ-осушитель азот (скорость - 10 л/мин); напряжение капилляра - $4000 \mathrm{~V}$; сканирование в диапазоне m/z 100 - 1000 .

Выводы. Впервые интерпретированы масс-спектры серии 1,2,4-триазол-3-тионов, промежуточных продуктов при синтезе активных фрармацевтических ингредиентов фрармацевтических препаратов. Показаны пути фрагментации и распада восьми 1,2,4-триазол-3-тионов.

Ключевые слова: масс-спектрометрия; высокоэффективная жидкостная хроматография; 1,2,4-триазол-3-тионы 


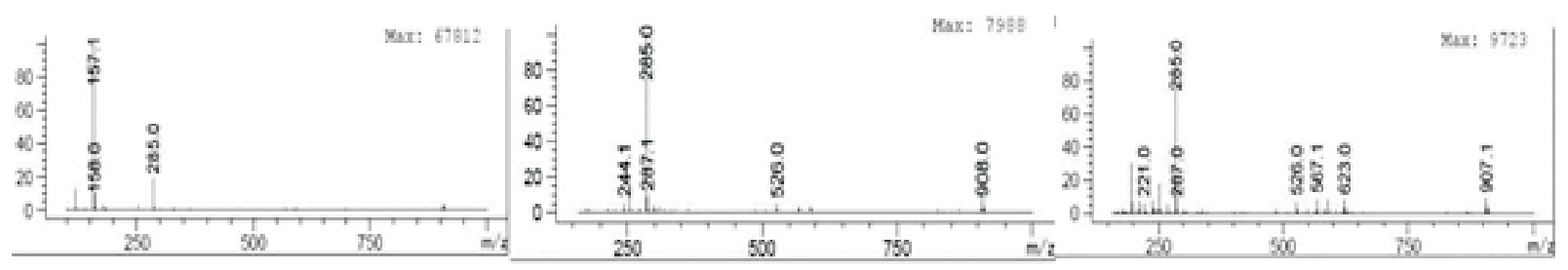

Fig. 1. Mass-spectra of 4-(2-methoxyphenyl)-5-(pyridin-4-yl)-2,4-dihydro-3H-1,2,4-triazole-3-thione at different fragmentor voltage (0, 100, 200 V)

Heterocyclic systems based on 1,2,4-triazole are the subject of interest for the present-day medicinal chemistry. They have the antioxidative, hepatoprotective and other activities; moreover, some of them have been already registered and used in the presentday veterinary (tryfusol, avesstym) [1, 2], and one of them is on the stage of registration for human use and manufacturing application (thiometrizol) [3].

In this way, the study of the preparation methods and the quality control of all stages of the development and production of the abovementioned compounds and their initial products in the synthesis is the urgent task for the present-day pharmaceutical science and of a scientific interest and practical importance.

One of the main methods, which may be used for the effective and reliable identification and the quantitative determination of the target products of the organic synthesis and impurities is chromatography

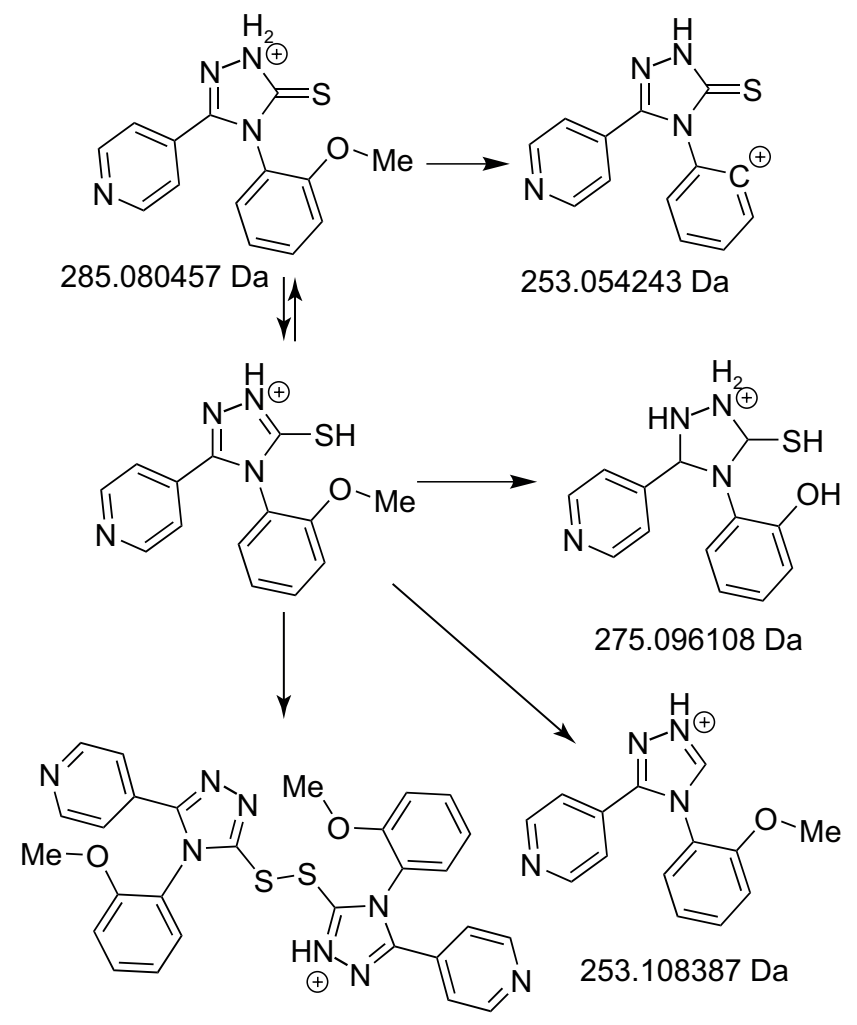

567.137988 Da

Fig. 2. The pathways proposed for the dissociation of 4-(2-methoxyphenyl)-5-(pyridin-4-yl)-2,4-dihydro-3H-1,2,4-triazole3-thione and theoretical monoisotopic masses of ions at $100 \mathrm{~V}$ with mass spectrometric detection. The most appropriate for the analytical goals is a combination of high performance liquid chromatography and mass spectrometry with ionization under atmospheric pressure, in electrospray (ESI), chemical ionization under atmospheric pressure (APCI), photochemical ionization under atmospheric pressure (APPI). The current work is devoted to ionization in electrospray, which is the best choice for the analysis of polar non-volatile compounds, such as the analytes under research.

At the first stage, there was the optimization of the mass spectrometry detection conditions [4], at the second stage the behavior of analytes to be chromatographed was studied [5].

Patterns of hydrazide of definite organic acids and their corresponding hydrazinecarbothioamides mass spectrometric decay were showed [6]. The mass fragmentation patterns of 1,2,4-triazole derivatives were reported in different articles [7-10].

The aim of the present work is to study massspectra and offer plausible fragmentation pathways of eight 1,2,4-triazole-3-thiones, the intermediate products in the synthesis of active pharmaceutical ingredients. The elucidation of fragmentation pathways was based on the electrospray ionization single quadrupole mass spectrometry.

\section{Results and discussion}

The mass spectra are presented in graphical and tabular form, providing the most intensive peaks starting about $1 \%$. The maximal peak was shown from isotope group peaks. All compounds can exist as a thiol and thione forms. We analyzed the mass spectra and suggested the possible fragmentation pathways of the compounds.

4-(2-Methoxyphenyl)-5-(pyridin-4-yl)-2,4dihydro-3H-1,2,4-triazole-3-thione. The ion with $\mathrm{m} / \mathrm{z} 285.0$ is observed at $0 \mathrm{~V}, 100 \mathrm{~V}$, and $200 \mathrm{~V}$ of collision voltages (Fig. 1). This ion corresponds to the quasimolecular ion (protonated molecule) of the current substance. The isotope peaks are also present in the mass spectrum. The ion with $\mathrm{m} / \mathrm{z} 253.1$ at $100 \mathrm{~V}$ and $200 \mathrm{~V}$ is detected (Fig. 2-3, Table 1); it is formed by heterolytic cleavage of bonds between a phenyl carbon and oxygen of the methoxy group. It is also possible that this ion corresponds to the structure created as a result of the sulfhydryl group cleavage from the quasimolecular ion. 


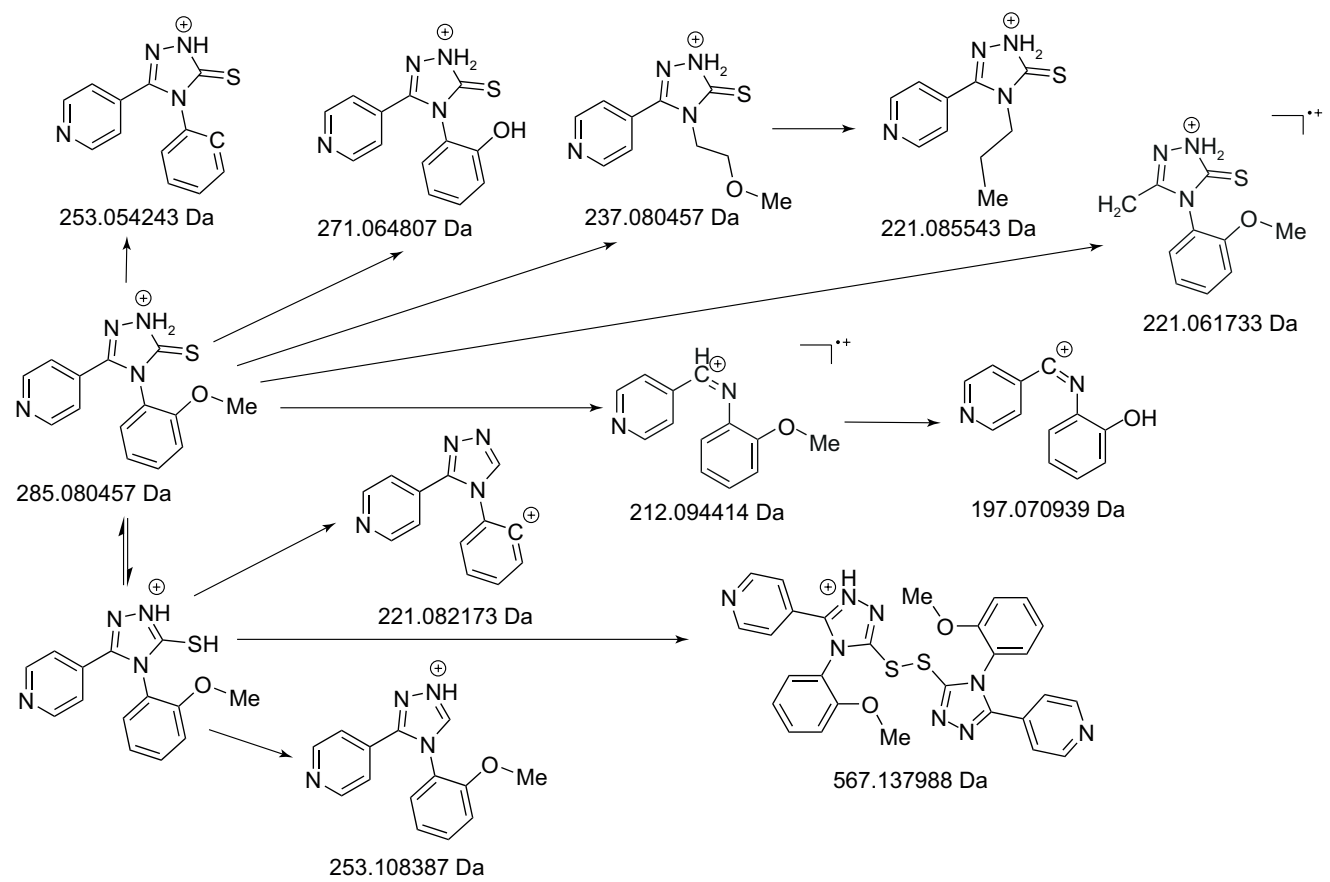

Fig. 3. The pathways proposed for the dissociation of 4-(2-methoxyphenyl)-5-(pyridin-4-yl)-2,4-dihydro-3H-1,2,4-triazole3 -thione and theoretical monoisotopic masses of ions at $200 \mathrm{~V}$

A pattern for the cation with $\mathrm{m} / \mathrm{z} 275.1$ appearing in the mass spectrum at $100 \mathrm{~V}$ has been offered (Fig. 2). The methoxy group elimination and the reduction of the triazol cycle are observed. The cation with

Table 1

The values of ions $\mathrm{m} / \mathrm{z}$ of $4-(2-$ methoxyphenyl)-5(pyridin-4-yl)-2,4-dihydro-3H-1,2,4-triazole-3-thione ions and the relative abundance at $100 \mathrm{~V}$ and $200 \mathrm{~V}$

\begin{tabular}{|c|r|r|}
\hline No & $\mathrm{m} / \mathrm{z}$ & Relative abundance, $\%$ \\
\hline \multicolumn{3}{|c|}{$100 \mathrm{~V}$} \\
\hline 1 & 253.1 & 14.7 \\
\hline 2 & 275.1 & 0.9 \\
\hline 3 & 285.0 & 100.0 \\
\hline 4 & 567.0 & 1.5 \\
\hline \multicolumn{3}{|c|}{$200 \mathrm{~V}$} \\
\hline 1 & 169.2 & 1.0 \\
\hline 2 & 184.0 & 1.2 \\
\hline 3 & 197.1 & 29.6 \\
\hline 4 & 212.1 & 6.7 \\
\hline 5 & 221.0 & 4.8 \\
\hline 6 & 237.1 & 6.6 \\
\hline 7 & 253.1 & 16.1 \\
\hline 8 & 269.9 & 4.8 \\
\hline 9 & 271.0 & 1.1 \\
\hline 10 & 285.0 & 100.0 \\
\hline 11 & 567.1 & 3.4 \\
\hline
\end{tabular}

\begin{tabular}{|c|c|c|}
\hline No & $\mathrm{m} / \mathrm{z}$ & Relative abundance, $\%$ \\
\hline \multicolumn{3}{|c|}{$100 \mathrm{~V}$} \\
\hline 1 & 212.0 & 2.0 \\
\hline 2 & 244.1 & 100.0 \\
\hline 3 & 485.0 & 1.7 \\
\hline \multicolumn{3}{|c|}{$200 \mathrm{~V}$} \\
\hline 1 & 105.1 & 27.6 \\
\hline 2 & 109.1 & 7.9 \\
\hline 3 & 115.1 & 1.4 \\
\hline 4 & 118.1 & 5.8 \\
\hline 5 & 130.0 & 3.1 \\
\hline 6 & 151.0 & 1.5 \\
\hline 7 & 157.0 & 7.2 \\
\hline 8 & 170.1 & 12.1 \\
\hline 9 & 185.1 & 10.6 \\
\hline 10 & 212.1 & 2.3 \\
\hline 11 & 216.0 & 3.0 \\
\hline 12 & 244.1 & 100.0 \\
\hline 13 & 265.0 & 1.0 \\
\hline 14 & 485.0 & 3.6 \\
\hline 15 & 485.0 & 1.7 \\
\hline & & \\
\hline
\end{tabular}

The values of ions $\mathrm{m} / \mathrm{z}$ of 5-(furan-2-yl)-4-phenyl2,4-dihydro-3H-1,2,4-triazole-3-thione and the relative abundance at $100 \mathrm{~V}$ and $200 \mathrm{~V}$ 

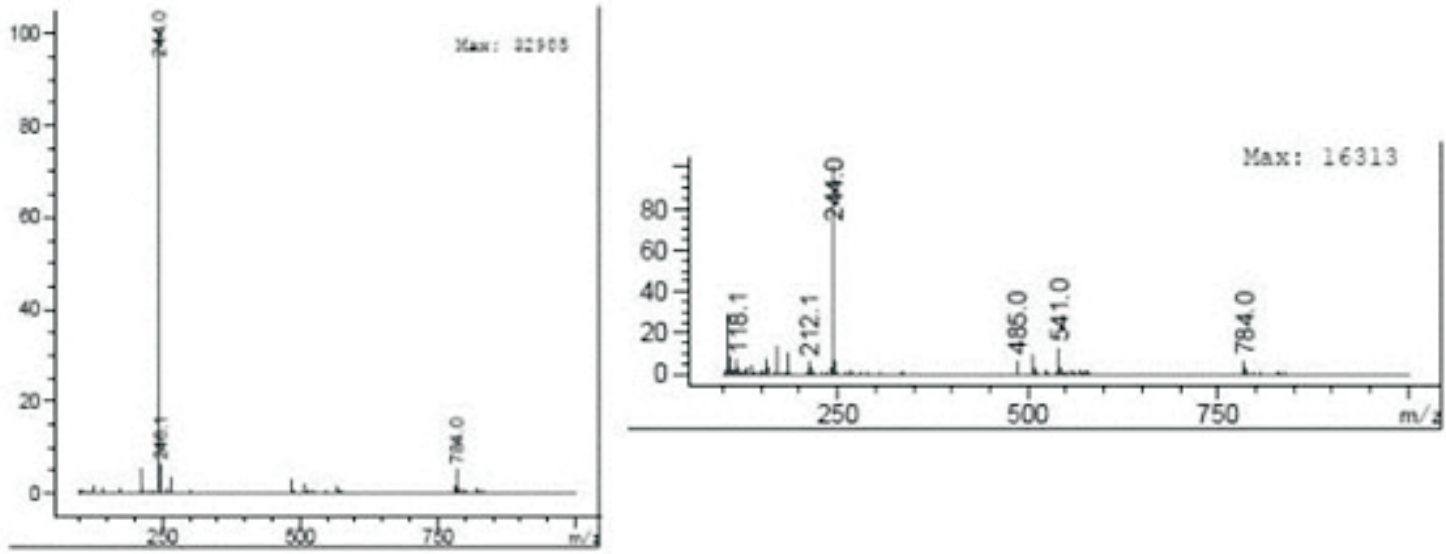

Fig. 4. Mass-spectra of 5-(furan-2-yl)-4-phenyl-2,4-dihydro-3H-1,2,4-triazole-3-thione at different fragmentor voltage (100, $200 \mathrm{~V})$

$\mathrm{m} / \mathrm{z} 567.1$ is the quasimolecular ion (a protonated dimer) of the compound at $0 \mathrm{~V}, 100 \mathrm{~V}$ and $200 \mathrm{~V}$. $200 \mathrm{~V}$ of collision voltage cause the appearance of the cation with $\mathrm{m} / \mathrm{z} 237.1$. (Fig. 3). It is formed due to partial destruction of the methoxyphenyl cycle. Several structures of the cation with $\mathrm{m} / \mathrm{z} 221.0$ have been offered. The first one is splitting off sulfur and the methoxyl group, it leads to formation of the phenylium carbocation. The second one is due to the destruction of the pyridin cycle, the corresponding cation radicals are formed, the third structure is due to the destruction of the metoxyphenyl cycle. The ion with $\mathrm{m} / \mathrm{z} 271.0$ appears during cleavage of the methyl group from a quasimolecular ion. The destruction of the triazole cycle is also possible with the formation of the following ions: the radical cation with $\mathrm{m} / \mathrm{z} 212.1$ and the cation with $\mathrm{m} / \mathrm{z} 197.1$ are formed.

5-(Furan-2-yl)-4-phenyl-2,4-dihydro-3H-1,2,4triazole-3-thione. At fragmentor voltage of $100 \mathrm{~V}$ the quasimolecular (protonated molecule) ion with $\mathrm{m} / \mathrm{z} 244.1$ and the dimer cation with $\mathrm{m} / \mathrm{z} 485.0$ are formed (Fig. 4, Table 2).<smiles>[CH]=Cc1nncn1-c1ccccc1</smiles>

170.071274 Da<smiles>C/C=C/c1nncn1-c1ccccc1</smiles>

185.094749 Da<smiles>c1ccc(-n2c(SSc3nnc(-c4ccco4)n3-c3ccccc3)nnc2-c2ccco2)cc1</smiles>

485.08489 Da<smiles>CC([NH-])N(C)c1ccccc1</smiles>

151.122975 Da 109.088601 Da<smiles>CC(C)(C)C</smiles>

212.081838 Da

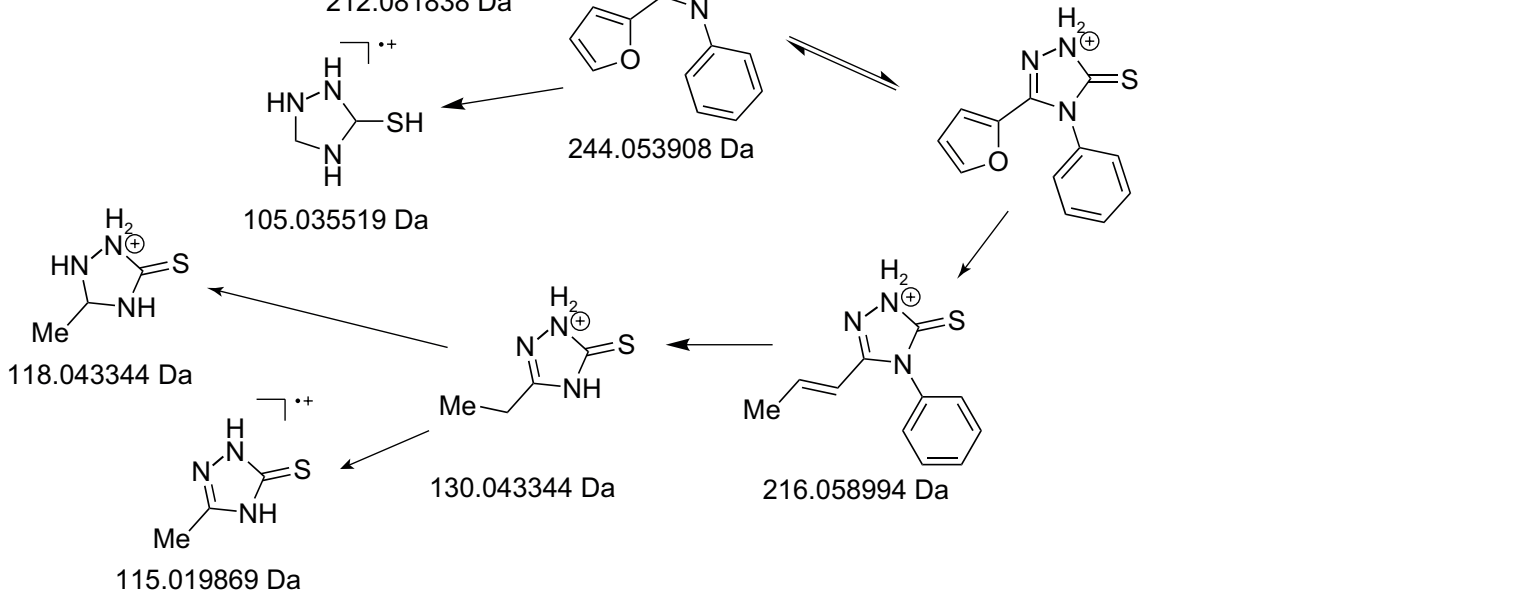

N-NH $170.071274 \mathrm{Da}$

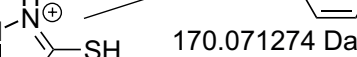

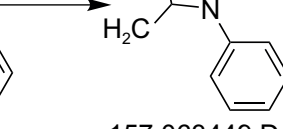

157.063449 Da

Fig. 5. The pathways proposed for the dissociation of 5-(furan-2-yl)-4-phenyl-2,4-dihydro-3H-1,2,4-triazole-3-thione and theoretical monoisotopic masses of ions at $200 \mathrm{~V}$ 

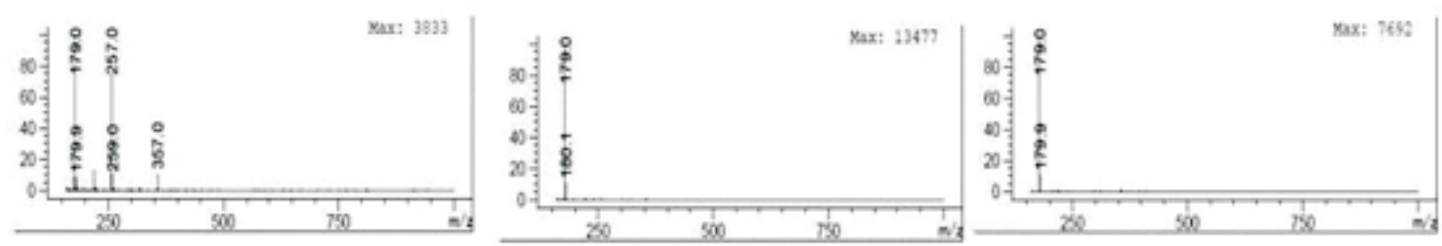

Fig. 6. Mass-spectra of 5-(pyridin-4-yl)-1,2-dihydro-3H-1,2,4-triazole-3-thione at different fragmentor voltage (0, 100, $200 \mathrm{~V})$

There is also the ion with $\mathrm{m} / \mathrm{z} 212.1$, which appears as a result of splitting off sulfur from a quasimolecular ion (Fig. 4). When the fragmentor voltage is increased from 100 to $200 \mathrm{~V}$, more than 10 new ions appear (Table 2, Fig. 5).

The ion with $\mathrm{m} / \mathrm{z} 212.1$ is also present at voltage of $200 \mathrm{~V}$. The radical cation with $\mathrm{m} / \mathrm{z} 185.1$ appears during cleavage of $\mathrm{CO}$ from the ion with $\mathrm{m} / \mathrm{z} 212.1$. In the case of additional splitting of the methyl group, the cation with $\mathrm{m} / \mathrm{z} 170.1$ appears. The alternative structure of the cation with $\mathrm{m} / \mathrm{z} 170.1$ may appear from a quasimolecular ion during the destruction of the furan cycle and elimination of the SH-group. With further cleavage of the methylene group the radical cation with $\mathrm{m} / \mathrm{z} 157.0$ appears. During disintegration of the triazole cycle the cation with $\mathrm{m} / \mathrm{z} 151.0$ appears at first, then the radical cation with $\mathrm{m} / \mathrm{z}$ 109.1. A direct elimination of the furan and benzene ring from thiol forms of a quasimolecular ion with the reduction of the triazole cycle; in this case, the appearance of the radical cation with $\mathrm{m} / \mathrm{z} 105.1$ is possible. If $\mathrm{CO}$ is cleaved from the quasimolecular ion, the cation with $\mathrm{m} / \mathrm{z} 216.1$ may be formed. This cation turns into the ion with m/z 130.0 after eliminating the methylene group and benzene ring. In the case of the triazole cycle reduction, the formation of the ion with $\mathrm{m} / \mathrm{z} 118.0$ is possible. The radical cation with m/z 115.1 may appear after cleavage of $\mathrm{CH}_{2}$ from the ion with $\mathrm{m} / \mathrm{z} 130.0$.<smiles>S=c1[nH]nc(-c2ccncc2)[nH]1</smiles>

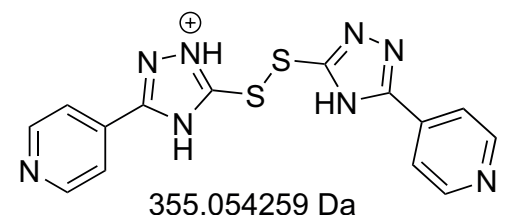<smiles></smiles>

179.031316 Da

357.069909 Da
5-(Pyridin-4-yl)-1,2-dihydro-3H-1,2,4-triazole-3-thione. At voltage of $0,100,200$, and $300 \mathrm{~V}$ the quasimolecular cation of the protonated substance with $\mathrm{m} / \mathrm{z} 179.0$ is observed in mass spectra, as well as the dimeric cation with $\mathrm{m} / \mathrm{z} 355.0$ and a partially hydrogenized dimeric cation with $\mathrm{m} / \mathrm{z} 357.0$ are formed (Fig. 6-7, Table 3).

At $0 \mathrm{~V}$ the adduct of the quazimolecular ion of the protonated ion exists with dimethyl sulfoxide with $\mathrm{m} / \mathrm{z}$ 257.0. The substance studied is solved in dimethyl sulfoxide. The scan range of $160-1000 \mathrm{~m} / \mathrm{z}$ is used for maximal exclusion of ions, which are the products of transformation of dimethyl sulfoxide in the ion source, it has not entirely obtained yet. The ions of product fragmentation of the compound studied have low intensity (less than $1 \%$ of the basic peak intensity); therefore, the interpretation of them is considered to be inappropriate.

5-(Morpholin-4-ylmethyl)-4-phenyl-2,4-dihydro-3H-1,2,4-triazole-3-thione. At voltage of $100 \mathrm{~V}$ the quasimolecular ion $\mathrm{MH}^{+}$with $\mathrm{m} / \mathrm{z}$ 277.1, as well as the ion with $\mathrm{m} / \mathrm{z} 245.1$ are present (Fig. 8, Table 4).

The ion with $\mathrm{m} / \mathrm{z} 245.1$ appears after cleavage of sulfur from a quasimolecular ion. The cation with

Table 3

The values of ions $\mathrm{m} / \mathrm{z}$ of 5-(pyridin-4-yl)-1,2-dihydro$3 \mathrm{H}-1,2,4$-triazole-3-thione and the relative abundance at $0 \mathrm{~V}, 100 \mathrm{~V}, 200 \mathrm{~V}$

\begin{tabular}{|r|r|r|}
\hline No & $\mathrm{m} / \mathrm{z}$ & Relative abundance, $\%$ \\
\hline \multicolumn{3}{|c|}{ 0 V } \\
\hline 1 & 172.0 & 0.8 \\
\hline 2 & 179.0 & 100.0 \\
\hline 3 & 257.0 & 71.9 \\
\hline 4 & 355.1 & 5.0 \\
\hline 5 & 357.0 & 10.2 \\
\hline \multicolumn{3}{|c|}{$100 \mathrm{~V}$} \\
\hline 1 & 179.0 & 100.0 \\
\hline 2 & 355.0 & 0.6 \\
\hline 3 & 357.0 & 0.5 \\
\hline \multicolumn{3}{|c|}{$200 \mathrm{~V}$} \\
\hline 1 & 179.0 & 100.0 \\
\hline 2 & 354.8 & 1.1 \\
\hline
\end{tabular}

Fig. 7. The pathways proposed for the dissociation of 5-(pyridin-4-yl)-1,2-dihydro-3H-1,2,4-triazole-3-thione and monoisotopic masses of ions 
Table 4

The values of ions $\mathrm{m} / \mathrm{z}$ of 5-(morpholin-4-ylmethyl)4-phenyl-2,4-dihydro-3H-1,2,4-triazole-3-thione and the relative abundance at $100 \mathrm{~V}$ and $200 \mathrm{~V}$

\begin{tabular}{|c|c|c|}
\hline No & $\mathrm{m} / \mathrm{z}$ & Relative abundance, $\%$ \\
\hline \multicolumn{3}{|c|}{$100 \mathrm{~V}$} \\
\hline 1 & 100.15 & 3.3 \\
\hline 2 & 102.15 & 1.1 \\
\hline 3 & 173.1 & 1.1 \\
\hline 4 & 245.05 & 2.2 \\
\hline 5 & 277.1 & 100.0 \\
\hline 6 & 551.15 & 3.5 \\
\hline \multicolumn{3}{|c|}{$200 \mathrm{~V}$} \\
\hline 1 & 100.1 & 100.0 \\
\hline 2 & 105.1 & 52.8 \\
\hline 3 & 117.1 & 12.1 \\
\hline 4 & 131.10 & 89.5 \\
\hline 5 & 136.0 & 9.5 \\
\hline 6 & 143.0 & 1.0 \\
\hline 7 & 148.0 & 4.0 \\
\hline 8 & 157.1 & 5.5 \\
\hline 9 & 163.0 & 7.3 \\
\hline 10 & 190.0 & 83.4 \\
\hline 11 & 277.1 & 8.1 \\
\hline 12 & 551.2 & 30.7 \\
\hline
\end{tabular}

$\mathrm{m} / \mathrm{z} 173.1$ is formed during forthcoming elimination of the phenyl radical and reduction of the triazole cycle. After cleavage of triazole, cations with m/z 102.1 and 100.1 appear (Fig. 9) [6].

At voltage of $200 \mathrm{~V}$ (Table 4, Fig. 10) the quasimolecular ion may be disintegrated in few ways. Firstly, after elimination of sulfur, the triazole cycle reduction and the morpholine fragment separation, the radical cation with $\mathrm{m} / \mathrm{z} 163.0$ is formed, and then after clea-
The values of ions $\mathrm{m} / \mathrm{z}$ of 4-methyl-5-(morpholin4-ylmethyl)-2,4-dihydro-3H-1,2,4-triazole-3-thione and the relative abundance at $100 \mathrm{~V}$ and $200 \mathrm{~V}$

\begin{tabular}{|c|c|c|}
\hline No & $\mathrm{m} / \mathrm{z}$ & Relative abundance, $\%$ \\
\hline \multicolumn{3}{|c|}{$100 \mathrm{~V}$} \\
\hline 1 & 100.1 & 1.6 \\
\hline 2 & 183.1 & 1.0 \\
\hline 3 & 215.1 & 100.0 \\
\hline 4 & 429.1 \\
\hline \multicolumn{3}{|c|}{$200 \mathrm{~V}$} \\
\hline 1 & 100.1 & 100.0 \\
\hline 2 & 128.1 & 15.7 \\
\hline 3 & 215.1 & 9.5 \\
\hline 4 & 427.1 & 1.9 \\
\hline
\end{tabular}

vage of the methylene radical the cation with $\mathrm{m} / \mathrm{z} 148.0$ is observed. The structure of the ion with $\mathrm{m} / \mathrm{z} 148.0$ is also possible; it corresponds to the cation, which appears during elimination of sulfur, the morpholinemethylene fragment and partial reduction of the triazole cycle. The cation with $\mathrm{m} / \mathrm{z} 136.0$ is formed after cleavage of sulfur, the morpholinemethylene fragment and partial destruction of the triazole cycle.

During elimination of the morpholine fragment from the quasimolecular ion the ion with $\mathrm{m} / \mathrm{z} 190.0$ appears. The alternative structure of the radical cation with $\mathrm{m} / \mathrm{z} 163.0$ may be obtained by destruction of the triazole cycle. Elimination of sulfur and the morpholine methylene fragment, the triazole cycle destruction lead to the appearance of the radical cation with $\mathrm{m} / \mathrm{z}$ 105.1. During cleavage of sulfur, the phenyl radical and the triazole cycle destruction the radical cation with $\mathrm{m} / \mathrm{z} 157.1$ is formed, it is successively transformed into the cation with $\mathrm{m} / \mathrm{z}$ 143.0, 131.1 and 100.1 (we suggested two structures; one of them was demonstrated in the previous research paper [6]). After elimination of the phenyl fragment and the morpholine cycle destruction the formation of the alternative
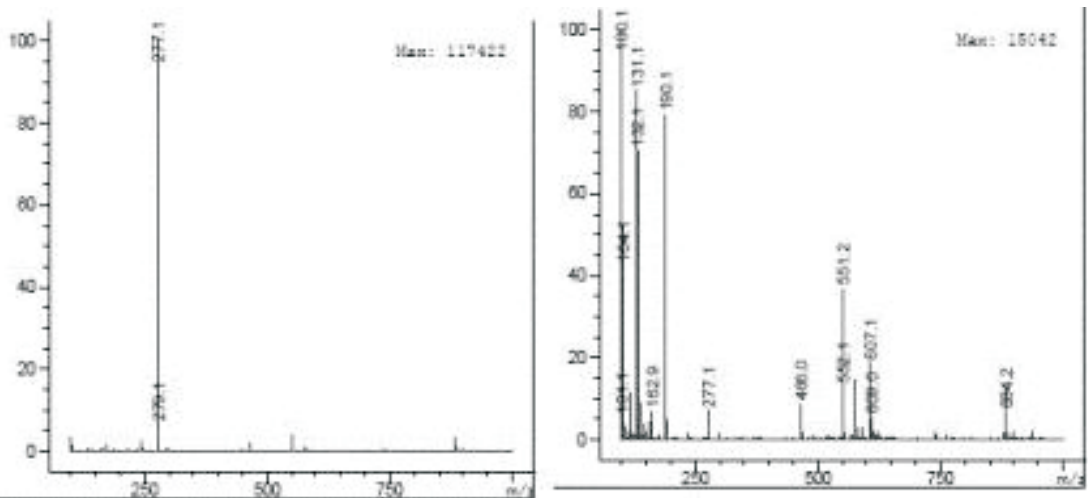

Fig. 8. Mass-spectra of 5-(morpholin-4-ylmethyl)-4-phenyl-2,4-dihydro-3H-1,2,4-triazole-3-thione (100, $200 \mathrm{~V})$ 
<smiles></smiles>

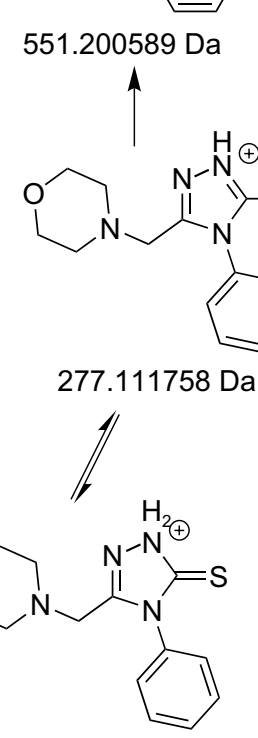<smiles></smiles>

$245.139688 \mathrm{Da}$

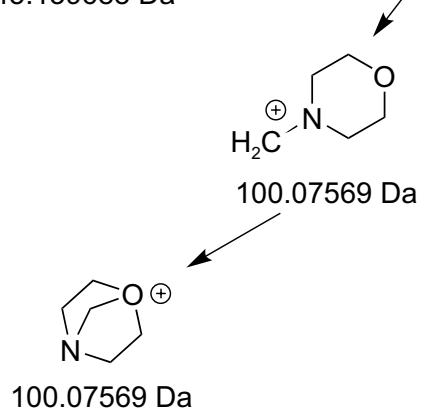

Fig. 9. The pathways proposed for the dissociation of 5-(morpholin-4-ylmethyl)-4-phenyl-2,4-dihydro-3H-1,2,4-triazole-3-thione and theoretical monoisotopic masses of ions at $100 \mathrm{~V}$

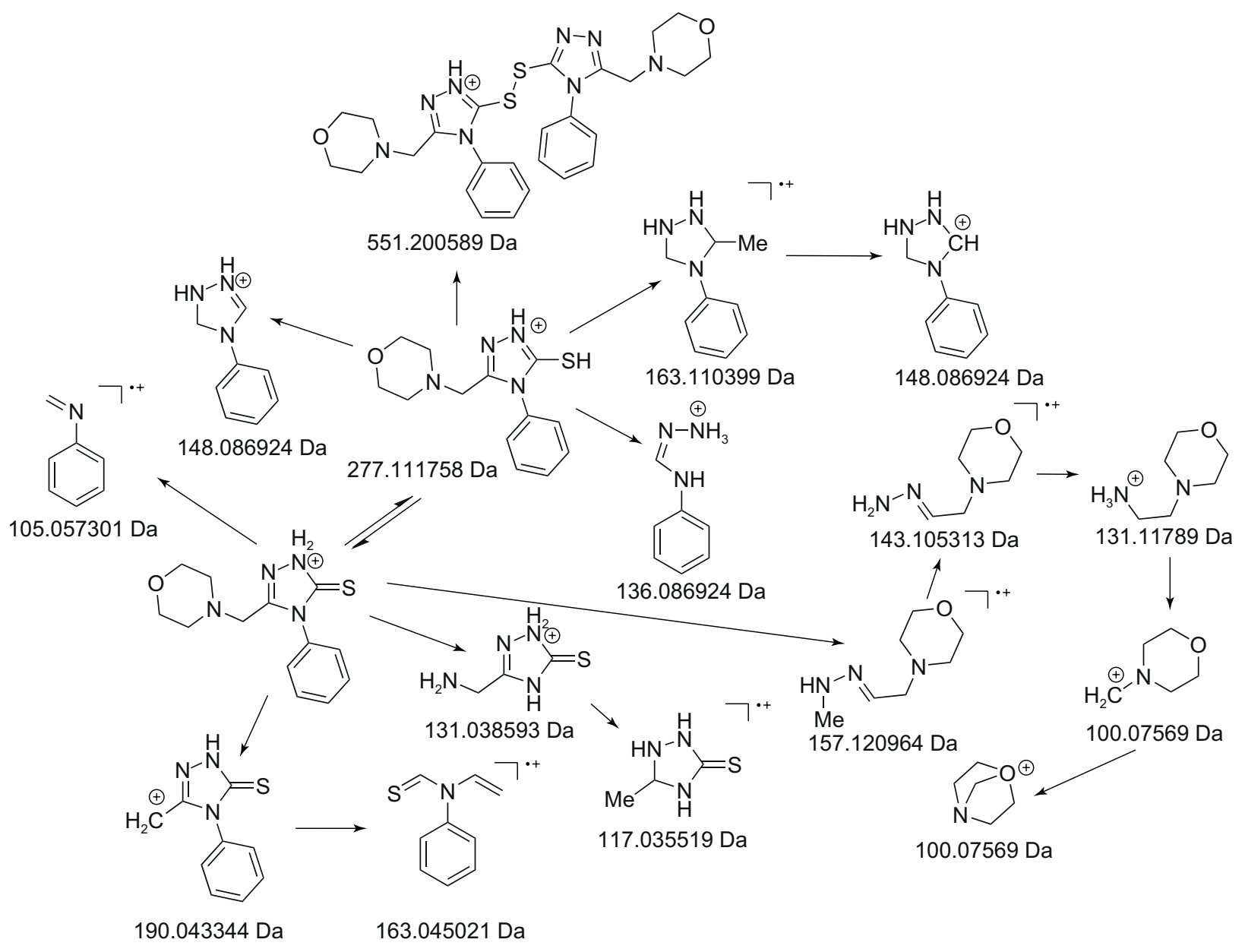

Fig. 10. The pathways proposed for the dissociation of 5-(morpholin-4-ylmethyl)-4-phenyl-2,4-dihydro-3H-1,2,4-triazole-3-thione and theoretical monoisotopic masses of ions at $200 \mathrm{~V}$ 

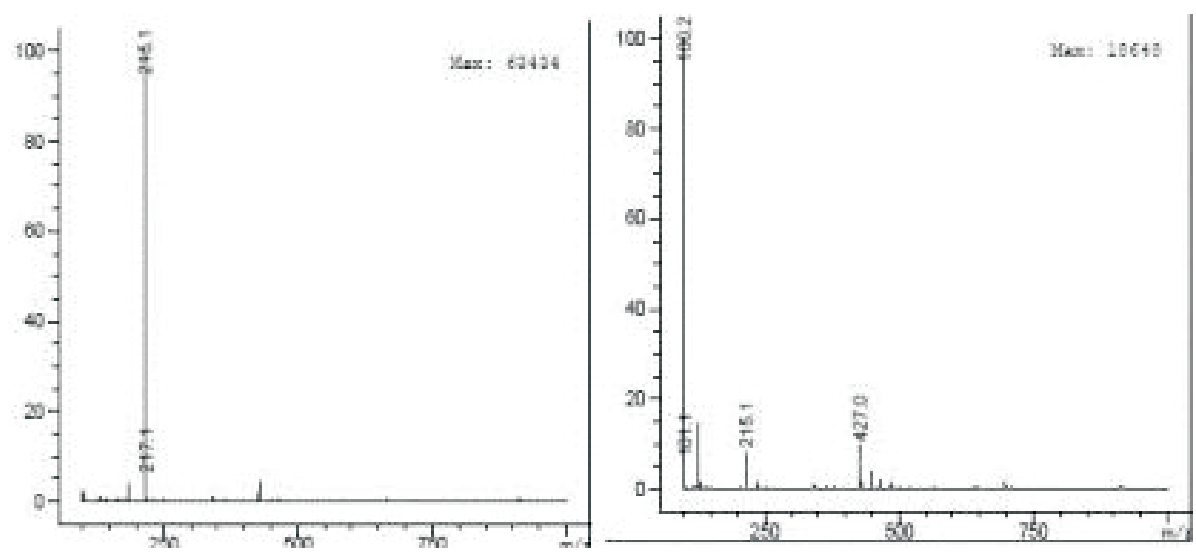

Fig. 11. Mass-spectra of 4-methyl-5-(morpholin-4-ylmethyl)-2,4-dihydro-3H-1,2,4-triazole-3-thione at different fragmentor voltage (100, $200 \mathrm{~V})$<smiles>Cn1c(CN2CCOCC2)nnc1CN1CCOCC1</smiles>

215.096108 Da

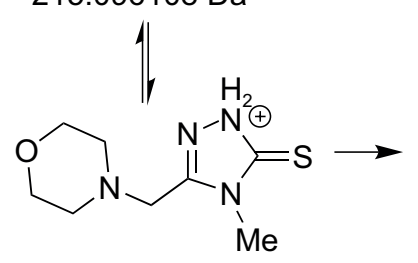

183.124038 Da<smiles>CN(C)C[C@@H]1CN(C)CCO1</smiles><smiles>CC1CN2CCOC1C2</smiles>

100.07569 Da

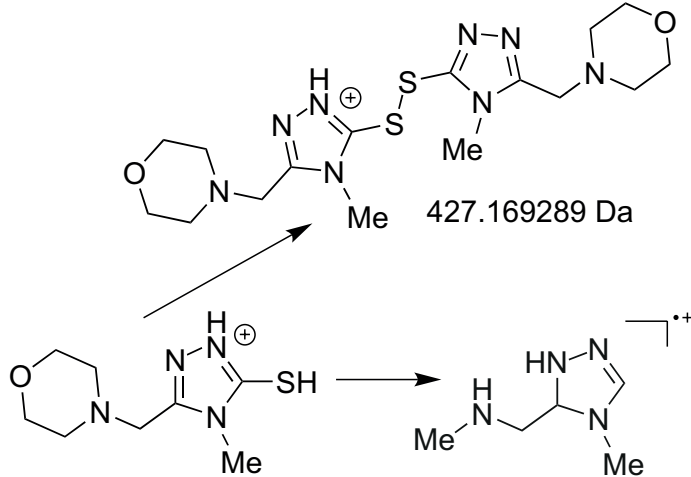

215.096108 Da

128.105678 Da<smiles>CSC1NN=C(CN2CCOCC2)N1C</smiles>

$\stackrel{\oplus}{\oplus}$<smiles>CN1CCOCC1</smiles>

100.07569 Da<smiles>IC1CN2CCOC1C2</smiles>

100.07569 Da
Fig. 12. The pathways proposed for the dissociation of 4-methyl5-(morpholin-4-ylmethyl)-2,4-dihydro-3H-1,2,4-triazole-3-thione and theoretical monoisotopic masses of ions at $100 \mathrm{~V}$
Fig. 13. The pathways proposed for the dissociation of 4-methyl5-(morpholin-4-ylmethyl)-2,4-dihydro-3H-1,2,4-triazole-3-thione and theoretical monoisotopic masses of ions at $200 \mathrm{~V}$
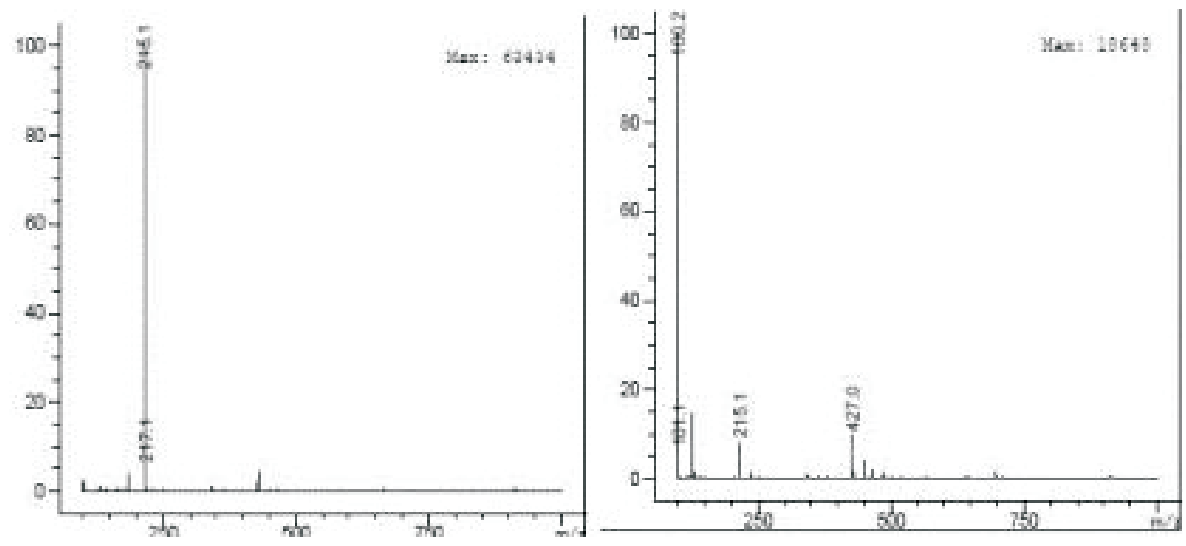

Fig. 14. Mass-spectra of 4-ethyl-5-(morpholin-4-ylmethyl)-2,4-dihydro-3H-1,2,4-triazole-3-thione at different fragmentor voltage (100, 200 V) 


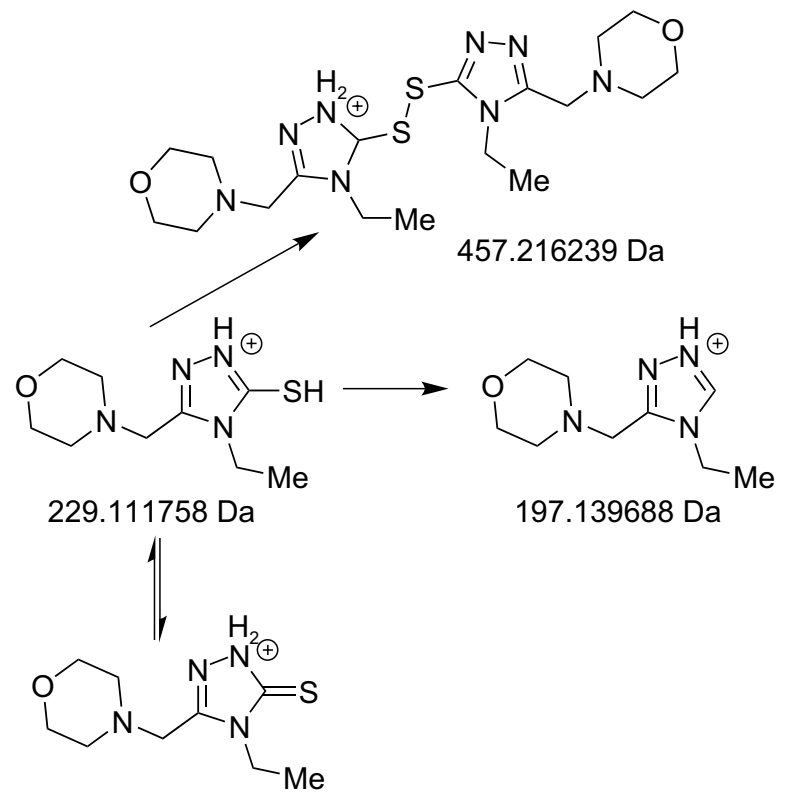

Fig. 15. The pathways proposed for the dissociation of 4-ethyl-5(morpholin-4-ylmethyl)-2,4-dihydro-3H-1,2,4-triazole-3-thione and theoretical monoisotopic masses of ions at $100 \mathrm{~V}$

structure of the cation with $\mathrm{m} / \mathrm{z} 131.1$ becomes possible, then it creates the cation with $\mathrm{m} / \mathrm{z}$ 117.1. At both voltages of $100 \mathrm{~V}$ and $200 \mathrm{~V}$ the protonated cation of the dimer of the compound with $\mathrm{m} / \mathrm{z} 551.2$ mentioned appears (Fig. 9-10).

4-Methyl-5-(morpholin-4-ylmethyl)-2,4-dihydro-3 $\mathrm{H}-1,2,4-$ triazole-3-thione. At the fragmentor voltage of $100 \mathrm{~V}$ the quasimolecular ion with $\mathrm{m} / \mathrm{z} 215.1$ of the compound itself can be observed. We can also mark the ion of the dimer of the substance with the reduction of one of the triazole cycle. The cation with m/z 183.1 appears as a result of eli-
Table 6

The values of ions $\mathrm{m} / \mathrm{z}$ of 4 -ethyl-5-(morpholin4-ylmethyl)-2,4-dihydro-3H-1,2,4-triazole-3-thione and the relative abundance at $100 \mathrm{~V}$ and $200 \mathrm{~V}$

\begin{tabular}{|c|c|c|}
\hline No & $\mathrm{m} / \mathrm{z}$ & Relative abundance, $\%$ \\
\hline \multicolumn{3}{|c|}{$100 \mathrm{~V}$} \\
\hline 1 & 197.1 & 1.5 \\
\hline 2 & 229.1 & 100.0 \\
\hline 3 & 457.2 & 10.6 \\
\hline \multicolumn{3}{|c|}{} \\
\hline 1 & 100.1 & 100.0 \\
\hline 2 & 114.0 & 3.0 \\
\hline 3 & 142.0 & 20.9 \\
\hline 4 & 229.1 & 17.7 \\
\hline 5 & 455.0 & 1.2 \\
\hline 6 & 457.1 & 1.4 \\
\hline
\end{tabular}

mination of sulfur from a quasimolecular ion. The formation of the cation with $\mathrm{m} / \mathrm{z} 100.1$ is possible after the destruction of the triazole cycle corresponding to the above-described morpholine methylene derivatives (Fig. 11-12, Table 5).

Voltage of $200 \mathrm{~V}$ initiates the formation of the quasimolecular ion with $\mathrm{m} / \mathrm{z} 215.1$ and the dimeric ion with $\mathrm{m} / \mathrm{z}$ 427.1. After elimination of sulfur and partial destruction of the morpholine cycle the radical cation with m/z 128.1 is observed. In the case of destruction of the triazole cycle morpholine methylene the cation with m/z 100.1 appears (Fig. 13, Table 5).<smiles></smiles>

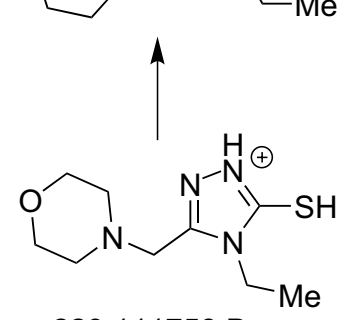
455.200589 Da<smiles>CCN1C(CN2CCOCC2)=NNC1SSc1nnc(CN2CCOCC2)n1CC</smiles>

457.216239 Da<smiles>CCn1c(CN2CCOCC2)n[nH]c1=S</smiles><smiles>CCN1C=NNC1CNC</smiles>

142.121298 Da<smiles>CCN1C=NOC1C</smiles>

114.102574 Da and theoretical monoisotopic masses of ions at $200 \mathrm{~V}$ 

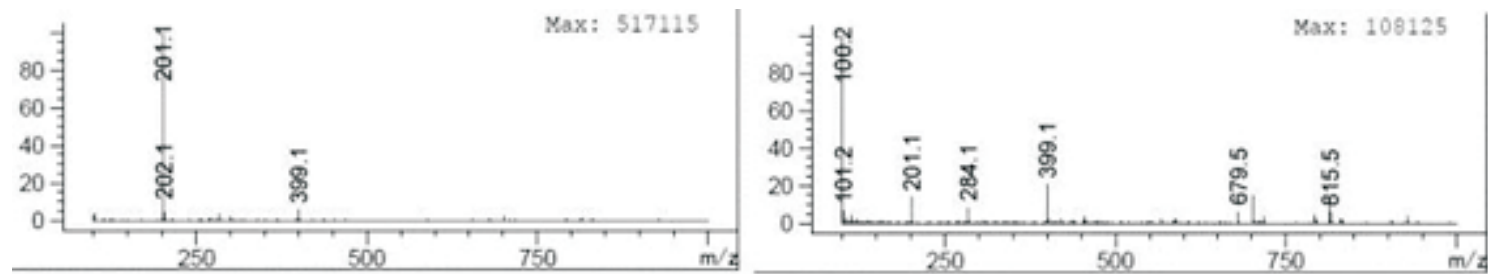

Fig. 17. Mass-spectra of 5-(morpholin-4-ylmethyl)-2,4-dihydro-3H-1,2,4-triazole-3-thione at different fragmentor voltage (100, $200 \mathrm{~V})$<smiles>CN1CCOCC1</smiles><smiles>S=c1nc(CN2CCOCC2)[nH][nH]1</smiles>

100.07569 Da<smiles>CCOCCN1CCOCC1</smiles>

100.07569 Da

Fig. 18. The pathways proposed for the dissociation of 5-(morpholin-4-ylmethyl)-2,4-dihydro-3H-1,2,4-triazole-3-thione and theoretical monoisotopic masses of ions at $100 \mathrm{~V}$<smiles>CN1CCOCC1CN1CCOCC1</smiles>
201.080457 Da 100.07569 Da 100.07569 Da<smiles>S=c1nc(CN2CCOCC2)[nH][nH]1</smiles>
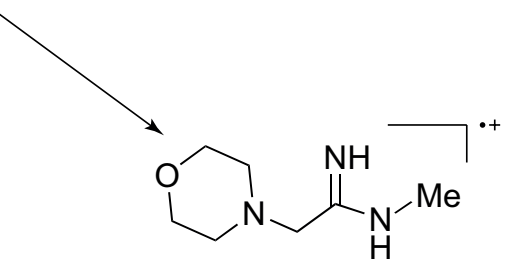

157.120964 Da

Fig. 19. The pathways proposed for the dissociation of 5-(morpholin4-ylmethyl)-2,4-dihydro-3H-1,2,4-triazole-3-thione and theoretical monoisotopic masses of ions at $200 \mathrm{~V}$ 

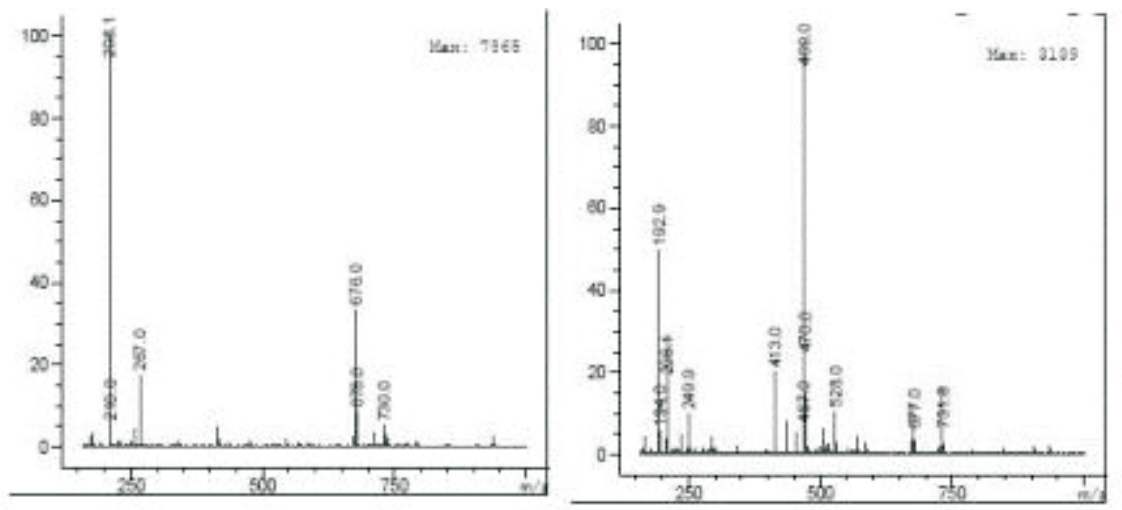

Fig. 20. Mass-spectra of 5-(2-methoxyphenyl)-2,4-dihydro-3H-1,2,4-triazole-3-thione at different fragmentor voltage (100, $200 \mathrm{~V})$

5-(Morpholin-4-ylmethyl)-2,4-dihydro-3H1,2,4-triazole-3-thione. The quasimolecular ion $\mathrm{MH}^{+}$ with $\mathrm{m} / \mathrm{z} 201.0$ and the dimer ion with $\mathrm{m} / \mathrm{z} 399.1$ are formed at $100 \mathrm{~V}$ (Fig. 17-18, Table 7).

Splitting off the triazole cycle causes the formation of the methylene morpholinium cation with $\mathrm{m} / \mathrm{z}$ 100.1. The quasimolecular ion of disintegration products appears at $200 \mathrm{~V}$. At the triazole cycle decay the cation with $\mathrm{m} / \mathrm{z} 157.1$ is formed. The cleavage of the morpholine radical causes the formation of the cation with $\mathrm{m} / \mathrm{z} 114.1$ (Fig. 19, Table 7).

5-(2-Methoxyphenyl)-2,4-dihydro-3H-1,2,4triazole-3-thione. The quasimolecular ion $\mathrm{MH}^{+}$with $\mathrm{m} / \mathrm{z} 208.0$ exists at $100 \mathrm{~V}$. It creates the dimeric ion of the compound with $\mathrm{m} / \mathrm{z} 413.0$ (Fig. 20-21, Table 8). Voltage of $200 \mathrm{~V}$ causes fragmentation of these ions. The cation with $\mathrm{m} / \mathrm{z} 176.0$ appears after cleavage of sulfur. The further elimination of the methyl group and the triazole cycle reduction cause the radical cation with $\mathrm{m} / \mathrm{z}$ 165.1. The cleavage of the methyl radical from the quasimolecular ion causes the formation of the radical cation with $\mathrm{m} / \mathrm{z}$ 193.0. Removing of an oxygen atom and proton is a possible cause of the alternative structures of the ion with $\mathrm{m} / \mathrm{z} 176.0$ (Fig. 22, Table 8).<smiles>COc1ccccc1-c1n[nH]c(SSc2nnc(-c3ccccc3OC)[nH]2)n1</smiles>

Fig. 21. The pathways proposed for the dissociation of 5-(2-methoxyphenyl)-2,4-dihydro-3H-1,2,4-triazole-3-thione and theoretical monoisotopic masses of ions at $100 \mathrm{~V}$

\section{Experimental part}

4-(2-Methoxyphenyl)-5-(pyridin-4-yl)-2,4-dihydro-3H-1,2,4-triazole-3-thione 1; 5-(furan-2-yl)4-phenyl-2,4-dihydro-3H-1,2,4-triazole-3-thione 2; 5-(pyridin-4-yl)-1,2-dihydro-3H-1,2,4-triazole3-thione 3; 5-(morpholin-4-ylmethyl)-4-phenyl-2,4dihydro-3H-1,2,4-triazole-3-thione 4; 4-methyl-5-(morpholin-4-ylmethyl)-2,4-dihydro-3 $H$-1,2,4-triazole3-thione 5; 4-ethyl-5-(morpholin-4-ylmethyl)-2,4-dihydro-3H-1,2,4-triazole-3-thione 6; 5-(morpholin-4ylmethyl)-2,4-dihydro-3 $\mathrm{H}$-1,2,4-triazole-3-thione 7; 5-(2-methoxyphenyl)-2,4-dihydro-3H-1,2,4-triazole3 -thione 8 were synthesized in the Zaporizhzhia State Medical University at the Department of Natural Sciences for Foreign Students and Toxicological Chemistry, Physical and Colloid Chemistry Department. The composition of compounds was confirmed by elemental analysis and IR, UV, ${ }^{1} \mathrm{H}$ NMR spectroscopy, chromatography with mass spectrometric detection.

Table 8

The values of ions $\mathrm{m} / \mathrm{z}$ of 5-(2-methoxyphenyl)-

2,4-dihydro-3H-1,2,4-triazole-3-thione and the relative abundance at $100 \mathrm{~V}$ and $200 \mathrm{~V}$

\begin{tabular}{|c|c|c|}
\hline No & $\mathrm{m} / \mathrm{z}$ & Relative abundance, $\%$ \\
\hline \multicolumn{3}{|c|}{$100 \mathrm{~V}$} \\
\hline 1 & 208.0 & 100.0 \\
\hline 2 & 413.0 & 6.2 \\
\hline \multicolumn{3}{|c|}{$200 \mathrm{~V}$} \\
\hline 1 & 165.1 & 5.2 \\
\hline 2 & 176.0 & 1.1 \\
\hline 3 & 193.0 & 55.6 \\
\hline 4 & 208.1 & 41.2 \\
\hline 5 & 413.0 & 23.2 \\
\hline
\end{tabular}


<smiles>COc1ccccc1-c1nnc(SSc2nnc(-c3ccccc3OC)[nH]2)[nH]1</smiles>

Fig. 22. The pathways proposed for the dissociation of 5-(2-methoxyphenyl)-2,4-dihydro-3H-1,2,4-triazole-3-thione and theoretical monoisotopic masses of ions at $200 \mathrm{~V}$

Acetonitrile (HPLC gradient grade), formic acid $(100 \%)$ were purchased from Merck KGaA (Darmstadt, Germany). Highly purified water $\left(18 \mathrm{M} \Omega\right.$ under $\left.25^{\circ} \mathrm{C}\right)$ was produced using the Direct Q 3UV Millipore system (Molsheim, France).

Sample solutions. Solutions of compounds 2, 4-7 in $50 \%$ acetonitrile and compounds $\mathbf{1}, \mathbf{3}, \mathbf{8}$ in dimethyl sulfoxide were prepared by dissolving to the final concentration of $1 \mathrm{mg} / \mathrm{mL}$.

Agilent 1260 Infinity HPLC System (degasser, binary pump, autosampler) with Agilent 6120 singlequadrupole mass-spectrometer and software OpenLAB CDS were used.

HPLC-MS conditions: 1) column - $\varnothing 4,6 \times 30 \mathrm{~mm}$, reversible phase Zorbax SB C18, $1.8 \mu \mathrm{m}$; 2) column temperature $-40^{\circ} \mathrm{C} ; 3$ ) eluent $\mathrm{A}-0.1 \% \mathrm{HCOOH}$ in $\mathrm{H}_{2} \mathrm{O}$; eluent $\mathrm{B}-0.1 \% \mathrm{HCOOH}$ in $\mathrm{CH}_{3} \mathrm{CN}$; isocratic mode $(50: 50, \mathrm{v} / \mathrm{v}) ; 4)$ the flow rate $-0.4 \mathrm{~mL} / \mathrm{min} ; 5)$ ion source - API-ES; 6) positive polarity; 7) drying gas nitrogen (rate - $10 \mathrm{~L} / \mathrm{min}$ ); 8) the capillary voltage $4000 \mathrm{~V}$; 9) scanning in the range of $\mathrm{m} / \mathrm{z} 100-1000$ and 160-1000 for compounds 2, 4-7 and 1, 3, 8, respectively.

\section{Conclusions}

1. The ESI mass spectra of eight 1,2,4-triazolethiones at different fragmentor voltage have been shown.

2. For the first time mass spectra of ESI 1,2,4-triazolethiones series, the intermediate materials in the synthesis of active pharmaceutical ingredients of pharmaceutical formulations has been interpreted.

3. The fragmentation pathways and patterns of eight 1,2,4-triazolethiones have been proposed.

Conflict of interests: authors have no conflict of interests to declare.

\section{References}

1. Pruglo, Ye. S.; Pohorlyuk, A. Yu.; Parchenko, V. V.; Panasenko, O. I.; Knysh, Ye. G. Antiviral activity of trifuzol for the broiler at poultry farm. Zaporozhye Medical Journal 2016, (1(94)), 77-80. https://doi.org/10.14739/2310-1210.2016.1.64062.

2. Бушуєва, І. В.; Березовський, А. В.; Книш, Є. Г.; Панасенко, О. І. Застосування препарату «Авесстим» для підвищення ефективності вакцинопрофілактики та вплив препарату на резистентність курчат. ScienceRise 2014, 4 (1(4)), 94-97. https://doi.org/10.15587/2313-8416.2014.29279.

3. Каплаушенко, А. Г. Дослідження зі створення нового оригінального вітчизняного лікарського засобу на основі 1,2,4-тріазолу. Науковий журнал МОЗ України 2013, 2(3), 115-121.

4. Varynskyi, B. O.; Kaplaushenko, A. G. Optimization of the detection conditions for the series of 1,2,4-triazole-3-thiones for FIA-ESI-MS and HPLCESI-MS. News of Pharmacy 2016, (1(85)), 7-11. https://doi.org/10.24959/nphj.16.2063.

5. Варинський, Б. О. Вивчення методом ВЕРХ-ДМД-МС закономірностей утримування ряду 1,2,4-тріазол-3-тіонів - напівпродуктів у синтезі активних фармацевтичних інгредієнтів. Фармаком 2016, (1), 32-40.

6. Варинський, Б. О.; Каплаушенко, А. Г.; Малецький, М. М.; Тімошик, Ю. В. Вивчення закономірностей мас-спектрометричного розпаду гідразидів деяких органічних кислот та їх відповідних гідразинокарботіоамідів. Український біофармацевтичний журнал 2015, (6(41)), 60-71.

7. Eswaran, S.; Adhikari, A. V.; Shetty, N. S. Synthesis and antimicrobial activities of novel quinoline derivatives carrying 1,2,4-triazole moiety. Eur. J. Med. Chem. 2009, 44 (11), 4637-4647. https://doi.org/10.1016/j.ejmech.2009.06.031.

8. Economou, A.; Botitsi, H.; Antoniou, S.; Tsipi, D. Determination of multi-class pesticides in wines by solid-phase extraction and liquid chromatography-tandem mass spectrometry. J. Chromatogr. A 2009, 1216 (31), 5856-5867. https://doi.org/10.1016/j.chroma.2009.06.031.

9. Salionov, V. A.; Varynskyi, B. A.; Parchenko, V. V. Mass-spectrometric fragmentation of sodium 2-(4-methyl-5-(thiophene-2-yl)-4H-1,2,4-triazole3-ylthio)acetate. Zaporozhye Medical Journal 2015, (5(92)), 93-96. https://doi.org/10.14739/2310-1210.2015.5.53774.

10. Gonsalves, A. R.; Pineiro, M.; Martins, J. M.; Barata, P. A.; Menezes, J. C. Identification of Alprazolam and its degradation products using LC-MS-MS. ARKIVOC 2010, 2010 (5), 128-141. https://doi.org/10.3998/ark.5550190.0011.513. 